\title{
Estimation of Losses and Damages Caused by Flash Floods in the Commercial Area of Kajang, Selangor, Malaysia
}

\author{
Md Azizul Bari \\ Institute for Environment and Development \\ Universiti Kebangsaan Malaysia \\ Bangi, 43600, Selangor, Malaysia \\ Email: ashraf.osman@durham.ac.uk \\ Lubna Alam* \\ Institute for Environment and Development \\ Universiti Kebangsaan Malaysia \\ Bangi, 43600, Selangor, Malaysia \\ Email: lubna762120@gmail.com \\ Md. Mahmudul Alam \\ School of Economics, Finance \& Banking \\ Universiti Utara Malaysia \\ Sintok 06010, Kedah, Malaysia \\ Email: rony000@gmail.com \\ Labonnah Farzana Rahman \\ Institute for Environment and Development \\ Universiti Kebangsaan Malaysia \\ Bangi, 43600, Selangor, Malaysia \\ Email: labonnah.deep@gmail.com
}

\section{Joy Jacqueline Pereira}

Institute for Environment and Development

Universiti Kebangsaan Malaysia

Bangi, 43600, Selangor, Malaysia

Email: pereirajoy@yahoo.com

* Corresponding author

\section{Citation Reference:}

Bari, A., Alam, L., Alam, M.M., Rahman, L.F. \& Pereira, J.J. (2021). Estimation of Losses and Damages Caused by Flash Floods in the Commercial Area of Kajang, Selangor, Malaysia. Arabian Journal of Geosciences, 14(3), 195. (online) https://doi.org/10.1007/s12517-021$\underline{06503-\mathrm{X}}$

This is a pre-publication copy.

The published article is copyrighted by the publisher of the journal. 


\title{
Estimation of Losses and Damages Caused by Flash Floods in the Commercial Area of Kajang, Selangor, Malaysia
}

\begin{abstract}
Flash flood is the most devastating natural disaster experienced in Malaysia. It can be defined as any high water flow caused by various factors such as rainstorms, slow water run-off, and broken dams. In Malaysia, the most typical and disruptive hydro-meteorological occurrences are flash floods, which are mostly faced by Malaysian cities including Kuala Lumpur and Kajang. However, flash floods may occur at any time of the year rather than during monsoon and can result in devastating losses and damages. Thus, several mitigation steps and estimations are warranted to handle flash floods, especially at the city level. Hence, this paper estimated the amount of direct loss and damage due to flash floods on the basis of the commercial area of Kajang City. This empirical study used primary data collected through direct face-to-face semi-structured interviews with 41 businessmen in the study area. The average estimated overall losses and damages per shop was RM4,510.07 due to flash floods at Kajang City in 2014, wherein the significant contribution comes from the economic side. This study's findings can serve as the baseline information for future studies on flash flood losses and damages. Furthermore, the present study suggests extensive institutional research for estimating losses and damages due to flash floods at the country level as an adaptation strategy.
\end{abstract}

Keywords: Flash Flood, Loss and Damage, Disaster, Climate Change, Kajang, Malaysia

\section{INTRODUCTION}

Flood refers to an overflow of water onto a normally dry area, which can be due to various factors including rainstorms, slow water run-off, broken dams, and extreme weather conditions as defined by the US National Weather Service. It is also predicted that climate change will increase the frequency and intensity of floods because of irregular rainfall patterns in Southeast Asia during the Northeast and Southeast monsoons (IPCC, 2014; Taib et al., 2016; Ahmed et al., 2018). For example, the river catchments in Malaysia are highly influenced by the monsoons in terms of long-duration rains. Therefore, there were prolonged flash floods on many stretches of the rivers in Malaysia (Hafiz et al., 2013) including the Langat River (Nokman, 2014). Similarly, climate change has caused potentially stronger rainfall events because warmer air holds more water. However, flash flood events are widely varied from place to place, depending on the local microclimatic changes, which are very challenging to predict. For example, a 1-h rain in Langat River and one of its tributaries, the Jelok River around KajangCity, caused a severe 1.5-m flooding in 2008 (Krishnan, 2008). Similarly, a 2-h rain in 2011 in the study area, i.e., Kajang City, was found to be the worst in the past decade (Fernandez, 2011).

According to Sanyal et al. (2004), a flash flood results from heavy rainfall within a short period of time or high river discharge. It can damage physical infrastructures such as houses, schools, health centers, roads, culverts, marketplaces, gabion embankments, spurs, and hand pumps. Natural disasters including frequent flash floods cause major damages to the society, and they are alarming when they occur in highly populated areas and areas with highly concentrated economic activities. For example, Kajang Town, located in the District of Kajang, Malaysia, is a potential economic zone; the flash flood events in this area are increasing over time. 
Reportedly, flash flood occurred in this area once in 2002, 2008, and 2011 each and thrice in 2014. The flash flood in 2008 was $0.5-1.5 \mathrm{~m}$ high, which flooded two-thirds of Kajang City (Krishnan, 2008).

Malaysia has experienced a very rapid urbanization process since World War II, especially after independence in 1957. The urbanization process has changed the land use pattern and urban structure. A larger portion of the former forest and agricultural areas have been cleared and replaced by concrete buildings, roads, and drainage systems that are impermeable. In recent years, several parts of Malaysia have been affected by severe flooding, known as localized flash floods and basin-wide floods on the major river systems. The severely affected river basins were Penang (Juru River Basin), Pahang (Pahang River Basin), Terengganu (Setiu River Basin), and Perak (Kinta River Basin). Similarly, the state of Perlis in the northern part of Peninsular Malaysia faced heavy floods in 2005, 2010, and 2011 (Lawal et al., 2014). Reportedly, the worst flood in the last 100 years in Segamat, Johor, occurred on January 12, 2007 (Asmara \& Ludin, 2014). Additionally, the impact of floods on Malaysia's socioeconomic condition is significant. For example, approximately 2.5 million people in urban areas have suffered extremely due to the floods in 2000 because their settlements were located in the flood plain areas of Malaysia (Noorazuan et al., 2003).

Basically, the impacts of floods are dependent on its duration and can be classified into shortand long-term impacts. Short-term impacts are visible during flash floods, and the damage can include death; injuries; loss of infrastructure; damage to businesses, crops, fisheries, livestock, and properties; and diseases. Conversely, long-term impacts are characterized as rebuilding of houses, infrastructures, and roads; loss of trade and industry; and costs of insurance and other properties (Chan, 2015). Thus, estimation methodologies of flood losses and damages are applied in many European countries (Meyer \& Messner, 2005) and worldwide (Dutta et al., 2003; Brida et al., 2013; Ogie et al., 2020). These methods are useful in conducting cost-benefit analyses of the economic feasibility of flood control measures. In Germany, the responsibility for flood policy lies with the individual federal states; hence, there are large differences in the character and application of flood estimation methods in these states. Although the assessment of flood losses and damages can be an essential tool for adaptation of disaster and climate change, it has not received much scientific attention, especially in the context of Malaysia. Therefore, the present study aims to measure the losses and damages caused by flash flood events in municipal commercial areas and to suggest adaptation options. The study focuses on two primary aspects: the estimation of economic losses and damages due to flash flood events and the estimation of physical losses and damages due to flash flood events.

\section{MATERIALS AND METHODS}

\subsection{Study area}

This study was conducted in the commercial area of Kajang Town in Selangor, Malaysia. The maps of the study area and flood-prone area of Kajang Town and the flood-affected map are processed using ArcGIS and Google Earth as shown in Figures 1 and 2. It is situated between $2^{\circ} 59^{\prime} 0^{\prime \prime} \mathrm{N}$ and $101^{\circ} 47^{\prime} 0^{\prime \prime} \mathrm{E}$ and $21 \mathrm{~km}$ from Kuala Lumpur. Kajang Town has a total population of 311,785 . This population has grown rapidly in the past few years, with an estimated growth of $9 \%$ per annum. The area lies at $28 \mathrm{~m}$ above sea level, and the climate is tropical. The total annual rainfall of the area ranges from 500 to $800 \mathrm{~mm}$, and the mean annual temperature is $24^{\circ} \mathrm{C}$, with a minimum of $17^{\circ} \mathrm{C}$ and a maximum of $30^{\circ} \mathrm{C}$. The area is one of the most intervened areas through various land resource conservation and rehabilitation activities. 
Development strategies of Kajang Town are focused on urbanization, and presently, the main land use types are residential, commercial, industrial, infrastructures, community facilities, and open spaces. According to the Kajang Municipal Council, agriculture is the largest land use (40\%) component for all areas under Kajang Town. However, at the center of Kajang Town, the land is used mostly for community facility components such as for residential (26\%), commercial $(2 \%)$, and industrial $(5 \%)$ purposes. The municipal council has allocated almost 3000 ha of land for the industrial needs and over 500 ha for business and services in the area. The council also declared that it had a total of almost 280,000 units of holdings from the subdistricts under its administration. The holdings were parts of enterprises, businesses, and homes as well as select properties (Merican, 2019).

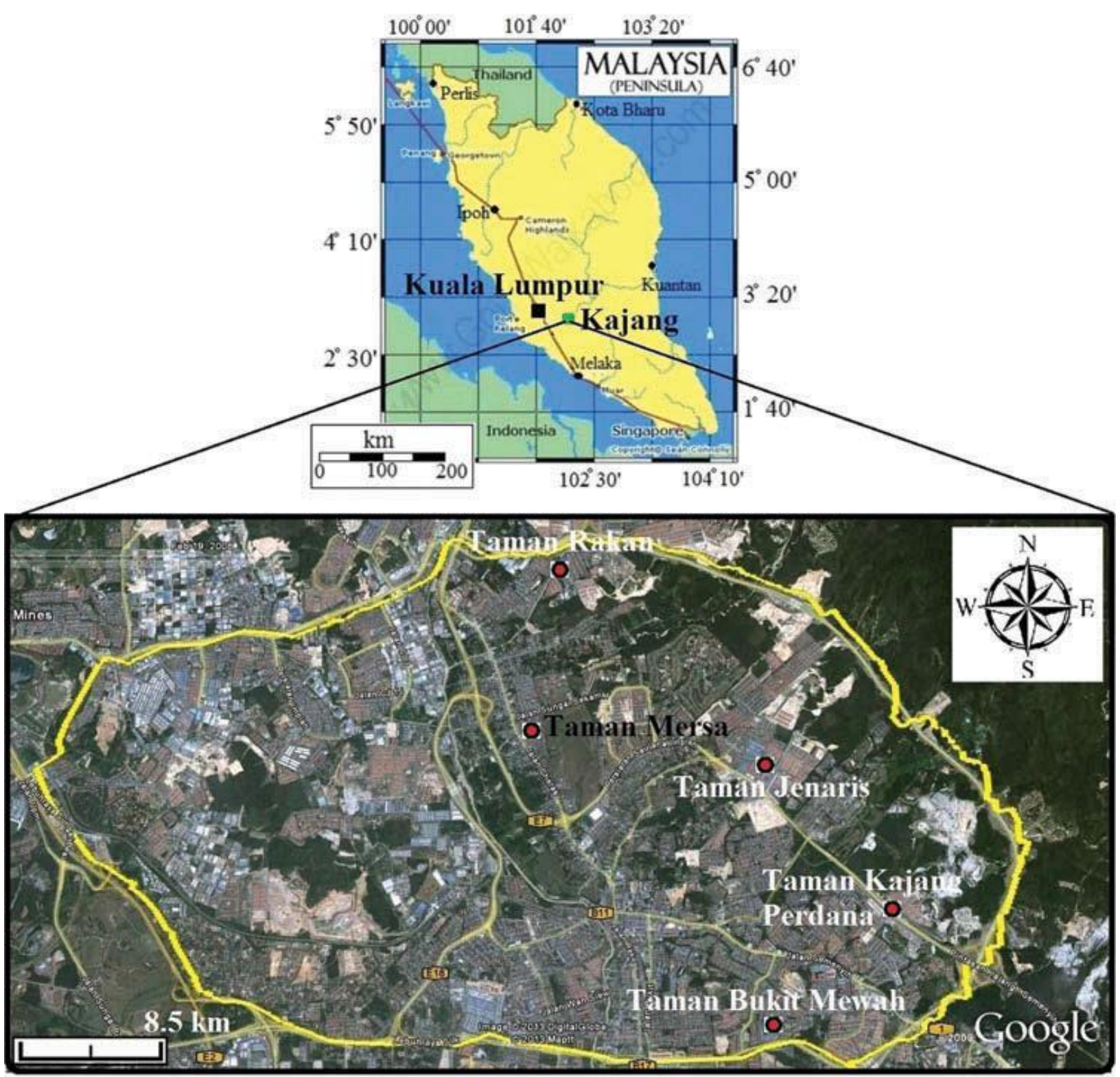

Figure 1: Location of the study area: Malaysia and Kajang City (Source: Abdullahi et al., 2015) 

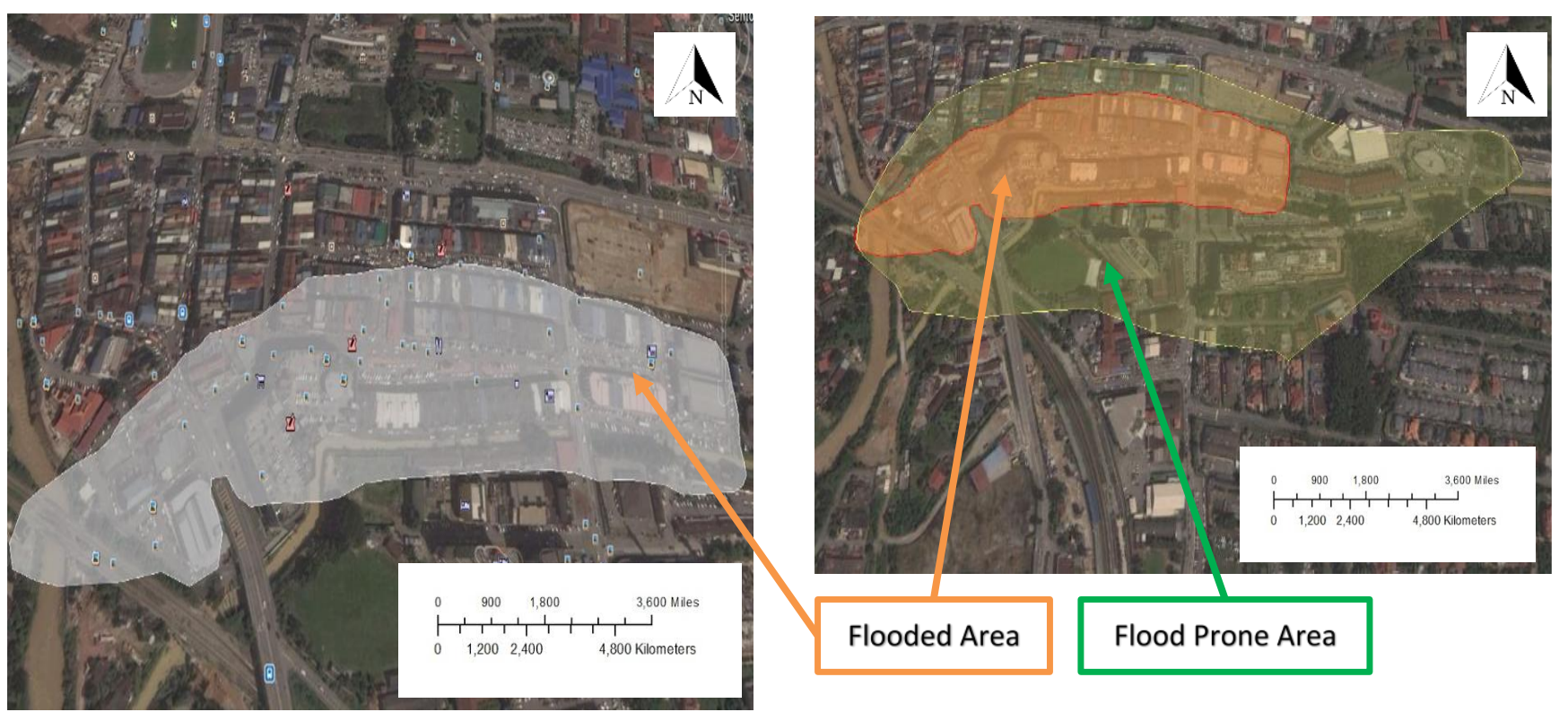

Figure 2: Study area in Kajang Town

\subsection{Data collection}

The direct face-to-face interview is the most commonly used approach in contingent valuation studies (Carson et al., 2001; Carson et al., 1996). The present study used market-based valuation methods (Carson, 2000; Carson \& Mitchell, 1993; Rioboca, 2014) to estimate the physical and economic losses and damages due to flash flood events. A face-to-face semistructured interview guide was formulated to collect the primary data. The research survey questionnaire comprised three main parts including section A (information on economic losses and damages such as sources of income, sources of income affected by flood, duration of shutdown business, types and cost of loss due to flood, opportunity cost, and clean-up cost); section B (information on physical losses and damages, such as type of building damaged, floor size of affected area, age and height of building, highest level of water from road surface, duration of water remained, number of person hired to repair the damage, duration of working to repair the damage, cost paid to the workers, type and cost of building material damaged, and effect of flood on the content of building); and section $\mathrm{C}$ (sociodemographic profile that included information on age, religion, gender, household size, children, education level, civil status, and monthly income). Collected data were analyzed using Excel statistical software.

The analysis was applied to Kajang City where severe flash floods have been recorded previously, but the survey was conducted from September to December 2015 to collect the loss and damage data for the latest flood that occurred in 2014. The flood started on December 20, 2014, with about half of Kajang Town submerged in floodwaters. The water level reached approximately 2 meters in some areas, and some cars were seen floating on the street (Victoria et al., 2014). The Department of Irrigation and Drainage straightened the river to combat flood problems in Semenyih, which used to affect several areas including Kampung Sungai Purun, Kampung Batu Tiga, and Rinching Hilir in Kajang. Therefore, whenever heavy rainfall occurs, the flow from upstream is extremely quick to reach Kajang City (Root, 2015).

The respondents of the study were the shop owners and shop keepers affected by the floods in the flood-prone areas of Kajang Town. The list of respondents was collected from the Kajang Municipal Council. It was followed by the purposive random sampling technique, which is explained by Bailey (1978) as a technique whereby the researcher uses their judgment about 
which respondents to choose and picks only those who can best meet the purposes of the study. A questionnaire guide technique was used to collect data from 41 samples.

\subsection{Estimation of physical losses and damages from flooding}

In Figure 3, the estimation criteria of the losses and damages due to economic and physiological impacts are described. However, the physical damages to buildings of commercial infrastructures have been analyzed using "cost of repair method" and "market price method." The cost to repair or clean up the property is used to determine the decrease in fair market value caused by the casualty (Smith \& Cuykendall, 1998), and the "market price method" estimates the economic value of goods or services that are bought and sold in markets (Carson \& Bergstrom, 2003). The "market price method" can be used to value changes in either the quantity or quality of a product or service. Furthermore, the "replacement method" and "cost of repair method" were applied to analyze the damage to other building contents and loss of vehicles. The term replacement cost or replacement value refers to the amount that an entity would have to pay to replace an asset at the present time according to its current worth (Thomas \& Wilson, 2005).

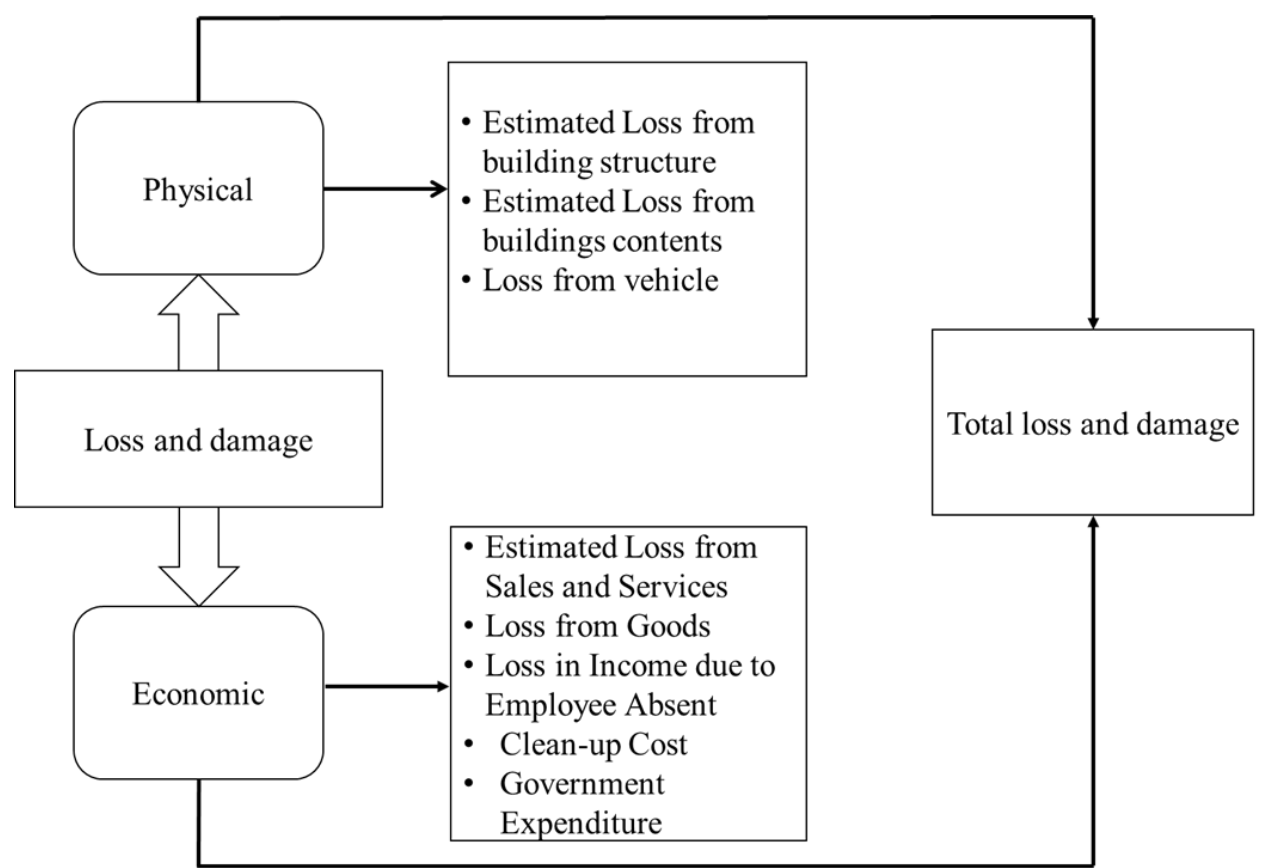

Figure 3: Losses and damages model for flood-prone city area (developed by the authors)

The equation of estimating physical losses and damages from flooding was shown as follows:

$$
\begin{aligned}
& E p d l_{i}=\sum_{i=1}^{n} E l b s_{i}+E l b c_{i}+L v_{i} \ldots \ldots \ldots \ldots \ldots(1) \\
& E l b s_{i}=\sum_{i=1}^{n}\left\{\left(N l h_{i} \times N d w_{i} \times W p d_{i}\right)+E_{c n m_{i}}\right\}
\end{aligned}
$$




$$
E l b c_{i}=\sum_{i=1}^{n}\left\{V d m_{i}+\left(R c m u_{i} \times N u_{i}\right)\right\}
$$

where

$$
\begin{aligned}
& E p d l_{i}=\text { estimated physical losses and damages } \\
& \text { Elbs } s_{i}=\text { estimated loss from building structure } \\
& \text { Elbc } c_{i}=\text { estimated loss from buildings content } \\
& L v_{i}=\text { loss from vehicle } \\
& N h_{i}=\text { number of labor hired } \\
& N d w_{i}=\text { number of days working } \\
& W p d_{i}=\text { wage per day } \\
& E c n m_{i}=\text { estimated costs of new materials } \\
& V d m_{i}=\text { value of totally destroyed materials } \\
& R c m u_{i}=\text { replacement costs of minor utensils } \\
& N u_{i}=\text { number of units }
\end{aligned}
$$

\subsection{Estimation of economic losses and damages from flooding}

The loss of income from sales and services and loss from goods has been calculated using the "market price method," whereas the loss in income due to employee absence was analyzed through "replacement costs method." "Clean-up cost method" will be used for removing the debris and sediments. The estimated economic losses and damages were computed as follows:

$$
\begin{aligned}
& \text { Epdl }_{i}=\sum_{i=1}^{n} \text { Elss }_{i}+\text { Lg }_{i}+\text { Liea }_{i}+\text { Clc }_{i}+G e_{i} \\
& \text { Elss }_{i}=\sum_{i=1}^{n}\left\{\left(\text { Aswof }_{i}-\text { Asw }_{i}\right) \times N s b_{i}\right\} \ldots \ldots \ldots \\
& \text { Liea }_{i}=\sum_{i=1}^{n}\left\{\left(N d a_{i} \times N e a_{i} \times W m_{i}\right) / 30\right\} \ldots \ldots \ldots \ldots
\end{aligned}
$$

where

Epdl $_{i}=$ estimated economic losses and damages

Elss $_{i}=$ estimated loss from sales and services

$L g_{i}=$ loss from goods

Liea $_{i}=$ loss in income due to employee absence

$\mathrm{Clc}_{i}=$ clean-up cost

$G e_{i}=$ government expenditure

Aswo $f_{i}=$ average daily sales without floods

Asw $f_{i}=$ average daily sales with flood events

$N s b_{i}=$ number of days of the shutdown of the business

$N d a_{i}=$ number of days of absence 
$\mathrm{Nea}_{i}=$ number of employee absence

$W m_{i}=$ wage per month

$N w h_{i}=$ number of workers hired

$N d w_{i}=$ number of days working

$W w d_{i}=$ wage of worker a day

\section{Results}

\subsection{Economic losses and damages}

The estimated loss in income due to flash flood events in the Kajang area is shown in Table 1. The highest cost has been recorded from sales and services with the value of Ringit Malaysia (RM) 73,920, which is $51.5 \%$ of the overall estimated loss. Similarly, the loss from damaged goods and commodities due to flash flood is also noteworthy, i.e., about 46\% (RM68,736) of the overall estimated loss as shown in Table 1 . The loss in income due to employee absence has had the minimum impact, which is estimated to be RM1,267 (0.8\%). During flood events, respondents just stayed in their respective areas and observed the behavior of the floodwater level. Some of the respondents secured their goods and material possessions to prevent damage in case of a worst-case scenario. Kajang City experienced the worst flash floods in nearly twothirds of the town area, and the floodwater remained for $2 \mathrm{~h}$. The water level rose between 0.5 and $1.5 \mathrm{~m}$ and brought traffic to a standstill in many parts of the town (Krishnan 2008). When the floodwater subsided, sediments were left inside and outside the vicinity of the shop as well as on the road; debris was also present after the floods. Family members and friends helped each other to clean the inside and outside of the shop. Some respondents also hired additional labor to perform the cleaning activities. The minimum payment for hired individuals was RM50 per day and the maximum was RM250 per day. Therefore, as shown in Table 1, the cost of cleaning and removing debris and sediments in the vicinity of the shop amounted to RM2,440.

Table 1: Estimation of average loss in income from sales and services and damage from goods and commodities due to the flash flood in 2014 in Kajang City's commercial areas

\begin{tabular}{|l|c|c|}
\hline Variables & Amount (RM) & \% \\
\hline Daily average sales and services without floods & 73,920 & \\
\hline Daily average sales and services with flood events & 22,910 & \\
\hline Loss in income from sales and services & $\mathbf{7 7 , 0 6 0}$ & 51.5 \\
\hline Fully damaged goods and commodities & 60,286 & \\
\hline Partially damaged goods and commodities & 8,450 & \\
\hline Overall damage from goods and commodities & $\mathbf{6 8 , 7 3 6}$ & 46.0 \\
\hline Number of days absent & 10 & \\
\hline Number of employees absent & 22 & \\
\hline Wage per day & 200 & \\
\hline Loss in income due to employee absence & $\mathbf{1 , 2 6 7}$ & 0.8 \\
\hline Number of workers hired & 26 & \\
\hline Number of days working & 12 & \\
\hline Wage of worker per day & $\mathbf{6 2 0}$ & \\
\hline Clean-up cost & $\mathbf{2 , 4 4 0}$ & 1.6 \\
\hline Government expenditure & $\mathbf{0}$ & 0.0 \\
\hline Estimated economic losses and damages & $\mathbf{R M 1 4 9 , 5 0 3}$ & 100.0 \\
\hline $\begin{array}{l}\text { Average estimated economic losses and damages } \\
\text { per shop* }\end{array}$ & $\mathbf{R M 3 , 6 4 6 . 4 1}$ & \\
\hline
\end{tabular}


*average is based on 41 samples

\subsection{Physical losses and damages}

The respondent's shops are usually located near the metro Kajang area. Some shops are built with concrete and strong materials. Some respondents experienced structure damage due to the flood, whereas others were not affected by it. The shops affected by the floods were situated near the Jelok and Langat Rivers. The affected shops were not completely damaged; instead, there were only some parts of the shop that were affected by the flood. Floods affected several parts of the settlement including the toilet and electrical wirings. The physical damage due to floods is also significant for economic activities. In the case of the building structure, the average loss has been recorded to be approximately RM17,130, which represents $48 \%$ of the overall physical loss, whereas the loss from building contents was RM14,380 as shown in Table 2. Aside from the value of the damage of the building structures, repair costs of vehicle were also significant, which contributes $11 \%$ of the overall average loss.

Table 2: Estimated average value of damage from the building structure and building contents due to flash flood in 2014 in Kajang commercial areas

\begin{tabular}{|l|c|c|}
\hline Variables & Amount (RM) & \% \\
\hline Building structure & & \\
\hline Number of laborers hired & 14 & \\
\hline Number of days working & 17 & \\
\hline Average wage per day & 53 & \\
\hline Estimated costs of new materials & 13,650 & \\
\hline Damage from a building structure & $\mathbf{1 7 , 1 3 0}$ & \\
\hline Value of completely destroyed materials & 3,350 & \\
\hline Replacement costs of minor utensils & 11,030 & \\
\hline Number of units & 16 & 11 \\
\hline Estimated loss from buildings contents & $\mathbf{1 4 , 3 8 0}$ & 100 \\
\hline Estimated repair costs of vehicle & $\mathbf{3 , 9 0 0}$ & \\
\hline Estimated physical losses and damages & $\mathbf{R M 3 5 , 4 1 0}$ & \\
\hline $\begin{array}{l}\text { Average estimated physical losses and damages } \\
\text { per shop* }\end{array}$ & $\mathbf{R M 8 6 3 . 6 6}$ & \\
\hline
\end{tabular}

*average is based on 41 samples

Average estimated overall losses and damages per shop due to flash floods in the Kajang area have been calculated to be RM4,510.07 (Combined from Tables 1 and 2) where maximum losses occurred in terms of economic loss $(81 \%)$. Diseases and illnesses emerged during and after the floods. However, for this study, it is found that the respondents were not affected by water-borne diseases. The Kajang hospitals and clinics were also not affected by the flood. Furthermore, the school children remained unaffected by flash floods because of school holidays during that time.

\section{DISCUSSION}

The interview with the businessmen, i.e., mainly shop owners, reported that flash floods due to short-term heavy rain had a significant impact on shutting down of their business activities. It is calculated through the interviews that on average, 1.49 days were unproductive not only due to the duration of the flood but also due to the cleaning and repairing activities. However, the daily economic loss from sales and services during a flood is also significant, i.e., around 51.5\%, 
compared with the overall average daily sales and services without a flood. Similarly, the loss of completely damaged goods and commodities due to a flash flood was $46.0 \%$. Therefore, the replacement cost of the goods and commodities by the shop owners/businessmen was quite high. Oh et al. (2013) also reported that during floods, roads, bridges, electricity, gas, and waste treatment facilities were severely affected, which negatively impacts the communities, such as the business community. Furthermore, Wealer (2014) reported about the severe flood at the Thailand-Myanmar border due to climate-induced variability during 2013 and that the government and non-government and private organizations need to collaborate better to minimize the impact of flood on the socioeconomic sector. A significant amount of economic damages due to flood events has been calculated to be RM8.74 billion, ranging from RM7.10 billion to RM10.38 billion in England (Environment Agency 2018). Evidence from a study showed that farmers can also be severely affected by floods with a limited capacity to cope and adapt (Brida et al., 2013). In the case of Malaysia, the flash flood of December 2014 can be classified as one of the worst floods with a massive impact on people, properties, agriculture, livestock, and infrastructure facilities (Buslima et al., 2018).

Accordingly, the physical losses and damages due to floods were also significant for the present study. In the case of the building structure, the repair cost of new materials was about $48 \%$ (RM17,130) of overall physical loss, whereas the estimated loss from building contents was $41 \%$. Similarly, repair costs related to vehicles were about 11\% (RM3,900). Therefore, the flood not only stops their economic activities but also restricts their movements. The flood damage study by the Environment Agency revealed that the business property damages can be significantly larger than household property damages (Environment Agency, 2018). The projected annual damages before and after land development in the development zone of Tainan were RM0.91 million and RM1.06 million, respectively (Yang et al., 2018). The physical impacts of some of the highly affected areas in Malaysia have been found to be unrecovered after about 8 months of the flood (Yahaya et al., 2015). In case of Kuala Lumpur City, a study showed that the roads and highways, houses, and vehicles were directly affected, damaged, and disrupted by flash foods (Bhuiyan et al., 2018). Various structured and nonstructured steps have been taken to reduce flash flood impact on Kuala Lumpur City, such as construction of smart tunnels, widening and deepening of the drainage systems, building reservoirs and dams for storm water at the upstream area, and cleaning of the main waterway of rivers (Samsuri et al., 2018). Although flooding has been a major problem since the 1970s, studies exploring loss and damage due to floods are extremely limited for this area. Flash floods are common, often receding after 1-4 hours of raining. Water levels have been reported to submerge houses along the river up to the roof level.

There are records of great floods occurring in Kajang during the years 1971, 1987, and 2011. Flash floods are also common with evidence of submerging houses along rivers up to the roof level (Muhamad, 2017). In Kajang, the event in December 2011 caused damages estimated to be RM2.4 million. Furthermore, at least three incidences were reported in 2014 causing losses estimated approximately RM150,000 per event (Muhamad, 2017). Most settlements and economic and development activities in Kajang are focused along the Jelok River (Muhamad, 2016).

Furthermore, some recommendations from the present study are highlighted below. The government should have a policy such as a subsidy or an incentive to the business community to combat the economic loss. Although there is a weather forecast system in Malaysia, the flood forecast, mainly from the excessive rain information, should be disseminated promptly to the local level, i.e., the business community and households. Therefore, they will get time to 
relocate their transferable goods, i.e., cars and small furniture, and will be able to reduce economic loss due to floods. The government should conduct awareness-raising activities such as increasing participation in flood insurance. First aid kits and other necessary medicines, i.e., oral saline, should be stocked not only in the local hospitals but also at the local level, i.e., shops, schools, and households. These medicines should be provided to the local levels by the government without any charge under the social development project. There should be a policy by the municipality regarding the cleaning activities after the flood to involve the businessmen as they know their requirements and priority of cleaning areas better. New research can be initiated for the long-lasting of products, i.e., furniture, wiring, and building construction materials, due to flooding. Extensive institutional studies are required to estimate losses and damages due to floods at the country level. Therefore, there should be adequate research by the planning division of the government as well as researchers of universities to find out the engineering solutions to minimize the impact of flood on the physical structure of the area, and there should be social research for building the resilience among the communities for sustaining the economic activities.

\section{CONCLUSIONS}

Flash floods are a common event in Malaysia; therefore, the study on urban flash floods is very substantial. This study identified the impact of flash flood events in Kajang City through estimating the losses and damages due to flash floods. The finding revealed that the average estimated overall losses and damages per shop was RM4,510.07. The present study also recommends management strategies such as introduction of proper subsidy or incentive policy, prompt dissemination of flood forecast, awareness-raising for increasing participation in flood insurance, and promotion of extensive research on flood losses and damages. However, the present study might not represent the flood scenario of elsewhere as it has conducted at the city level and focused only on business professionals. Thus, future research should investigate the uncertainty associated with the proposed measurement. Furthermore, there are scopes of further research by comparing few flood events with the volume, duration, water flow speed, and water quality. Additionally, the present study suggests future estimation of losses and damages considering other aspects, especially socioeconomic indicators, to get a better reflection of the event.

\section{ACKNOWLEDGEMENT}

We would like to thank all the people and organizations that contribute to this research and toward the completion of this article. This research is funded by the Ministry of Higher Education Malaysia (TRGS/1/2015/UKM/02/5/2) and START under the PARR fellowship program.

\section{REFERENCES}

Abdullahi, S., B. Pradhan, et al. (2015). "GIS-based modeling for the spatial measurement and evaluation of mixed land use development for a compact city." GIScience \& Remote Sensing 52(1): 18-39.

Ahmed MF, Alam L, Mohamed CAR, Mokhtar MB, Ta GC (2018) Health risk of Polonium 210 ingestion via drinking water: an experience of Malaysia. International journal of environmental research and public health 15(10):2056. 
Ahmed, M. F., L. Alam, et al. (2018). "Health risk of Polonium 210 ingestion via drinking water: An experience of Malaysia." International journal of environmental research and public health 15(10): 2056.

Asmara, T. T. and A. M. Ludin (2014). Mapping perception of community preparedness towards flood in Muar river, Johor Malaysia. IOP Conference Series: Earth and Environmental Science, IOP Publishing.

Bailey, K.D. (1978). Methods of social research. The Free Press, Avenue of the Americas, New York, 10020. 4th edition. Page: 83

Bhuiyan, T. R., M. I. Hasan, et al. (2018). "Direct Impact of Flash Floods in Kuala Lumpur City: Secondary Data-Based Analysis." ASM Science Journal 11(3): 145-157.

Brida, A.-B., T. Owiyo, et al. (2013). "Loss and damage from the double blow of flood and drought in Mozambique." International Journal of Global Warming 5(4): 514-531.

Buslima, F., R. C. Omar, et al. (2018). "Flood and flash flood geo-hazards in Malaysia." International Journal of Engineering and Technology(UAE) 7(4): 760-764.

Carson, R. M., \& Bergstrom, J. C. (2003). A review of ecosystem valuation techniques (No. 1607-2016-134549) [https://ageconsearch.umn.edu/record/16651/files/fs0303.pdf] Sited: $29 / 08 / 2020$.

Carson, R. T. (2000). Contingent valuation: a user's guide, ACS Publications.

Carson, R. T. and R. C. Mitchell (1993). "Contingent valuation and the legal arena." In: Valuing Natural Assets: The Economics of Natural Resource Damage Assessment, By Raymond J. Kopp, V. Kerry Smith, pp: 231-244.

Carson, R. T., N. E. Flores, et al. (1996). "Contingent valuation and revealed preference methodologies: comparing the estimates for quasi-public goods." Land economics 72(1): 80-99.

Carson, R. T., N. E. Flores, et al. (2001). "Contingent valuation: controversies and evidence." Environmental and resource economics 19(2): 173-210.

Chan, N. W. (2015). Impacts of disasters and disaster risk management in Malaysia: The case of floods. Resilience and recovery in Asian disasters, Springer, p. 239-265.

Dutta, D., S. Herath, et al. (2003). "A mathematical model for flood loss estimation." Journal of hydrology 277(1-2): 24-49.

Environment Agency (2018) Estimating the economic costs of the 2015 to 2016 winter floods. by: Environment Agency Horizon House, Deanery Road, Bristol BS1 5AH.

Fernandez C (2011) Kajang residents want an end to flood woes. Ministry of Natural Resources and Environment, The Star. Jan 2011. Online source: [https://www.thestar.com.my/news/community/2011/01/17/kajang-residents-want-anend-to-flood-woes/] Sited: 29/08/2020.

Hafiz, I., M. Nor, et al. (2013). Flood forecasting and early warning system for Dungun River Basin. IOP Conference Series: Earth and Environmental Science, IOP Publishing Ltd. p 012-129

IPCC (2014) Climate Change 2014: Impacts, Adaptation, and Vulnerability. Part B: Regional Aspects. Contribution of Working Group II to the Fifth Assessment Report of the Intergovernmental Panel on Climate Change. Cambridge University Press, Cambridge, United Kingdom and New York, NY, USA

Krishnan G (2008) Worst flood in Kajang. The Star Online. Star Media Group Berhad, Online source: [https://www.thestar.com.my/news/community/2008/10/17/worst-flood-inkajang.] Sited: 29/08/2020

Lawal, D. U., A.-N. Matori, et al. (2014). Analysis of the flood extent extraction model and the natural flood influencing factors: A GIS-based and remote sensing analysis. IOP Conference Series: Earth and Environmental Science, IOP Publishing. 
Merican, M (2019) Hulu Langat: A Glimpse of the Past, Media Selangor Sdn Bh, Online source: [https://selangorjournal.my/2019/07/hulu-langat-a-glimpse-of-the-past/] Sited: $29 / 08 / 2020$

Meyer, V. and F. Messner (2005). National flood damage evaluation methods: a review of applied methods in England, the Netherlands, the Czech Republik and Germany, UFZ Discussion Paper.

Muhamad, N. (2016). Natural Hazards in Built-up Area: A Case Study of Langat Sub-Basin. PhD Thesis, Southeast Asia Disaster Prevention Research Initiaves (SEADPRI-UKM), Universiti Kebangsaan Malaysia.

Muhamad, N., Lim C.L. and Pereira, J.J. (2017). Flood Hazard Mapping in Kajang, Malaysia, In book: Co-designing Disaster Risk Reduction Solutions: Towards Participatory Action and Communication in Science, Technology and Academia Chapter: 32 Publisher: Croucher Foundation Editors: Rajib Shaw, Emily Y. Y. Chan, Fang Lian, Lucy Lu, Peijun Shi, Saini Yang, Gloria K. W. Chan, Jennifer S. T. Wong

Nokman FS (2014) Retention pond to mitigate floods in Kajang. New Straits Times, 21 November. Online source: [https://www.klik.com.my/item/document/9926577/nst---fri11-2014-streets-210021-c-central] Sited: 29/08/2020

Noorazuan, M., R. Rainis, et al. (2003). GIS application in evaluating land use-land cover change and its impact on hydrological regime in Langat River basin, Malaysia. 2nd annual Asian conference of map Asia. [https://www.researchgate.net/profile/Rainis_Ruslan/publication/255590921_GIS_Appl ication_in_Evaluating_Land_Use-

Land_Cover_change_and_its_Impact_on_Hydrological_Regime_in_Langat_River_Bas in_Malaysia/links/54e2914b0cf2edaea09313be.pdf] Sited: 29/08/2020

Ogie, R. I., C. Adam, et al. (2020). "A review of structural approach to flood management in coastal megacities of developing nations: current research and future directions." Journal of Environmental Planning and Management 63(2): 127-147.

Oh, E. H., A. Deshmukh, et al. (2013). "Criticality assessment of lifeline infrastructure for enhancing disaster response." Natural Hazards Review 14(2): 98-107.

Rioboca J (2014) Valuation of flood impact of typhoon in certain town of mindanao south Philippines. PhD Thesis, University of the Philippines Los Baños, Philippines

Root, (2015). Kajang flood mystery no more. The Mole - MOLE.my Jan 6. Online source: [http://mole.my/kajang-flood-mystery-no-more/] Sited: 29/08/2020

Samsuri, N., R. Abu Bakar, et al. (2018). "Flash flood impact in Kuala Lumpur-Approach review and way forward." International Journal of the Malay World and Civilisation 6(Special Issue 1): 69-76

Sanyal, J. and X. Lu (2004). "Application of remote sensing in flood management with special reference to monsoon Asia: a review." Natural Hazards 33(2): 283-301.

Smith SF, Cuykendall CH (1998) Determining and Reporting Income Tax Losses and Gains From Storm Damage, Department of Agricultural Resource and Managerial Economics, College of Agriculture and Life Sciences, Cornell University, Ithaca, New York 148537801

Taib, Z. M., N. S. Jaharuddin, et al. (2016). "A Review of Flood Disaster and Disaster Management in Malaysia." International Journal of Accounting, Business and Management 4(2):97-105

Thomas, J. E., and Wilson, B. M. (2005). The Indemnity Principle: Evolution from a Financial to a Functional Paradigm. Journal of Risk Management \& Insurance, 10(30): 1-16.

Victoria B, Hui BY, Cheng N (2014). "Kajang struck by flash floods after heavy rain." The Star. 20 December. Online source: 
[https://www.thestar.com.my/news/nation/2014/12/20/kajang-flash-floods]

Sited: $29 / 08 / 2020$

Wealer, P. (2014). "Public Loss and Damage Inventories to Reduce Disaster Risk in Poor Countries: The Assessment of Climate-Change-Related Extreme Events in Myanmar." United Nations Peace and Progress. 2(1): 2-22.

Yahaya NS, Lim C-S, Jamaluddin UA, Pereira JJ (2015). The December 2014 flood in Kelantan: A post-event perspective. Warta Geologi (Newsletter of the Geological Society of Malaysia), 41 (3-4): 54,

Yang S-Y, Chan M-H, Chang C-H, Chang L-F (2018). The damage assessment of flood risk transfer effect on surrounding areas arising from the land development in Tainan, Taiwan. Water 10 (4):473 